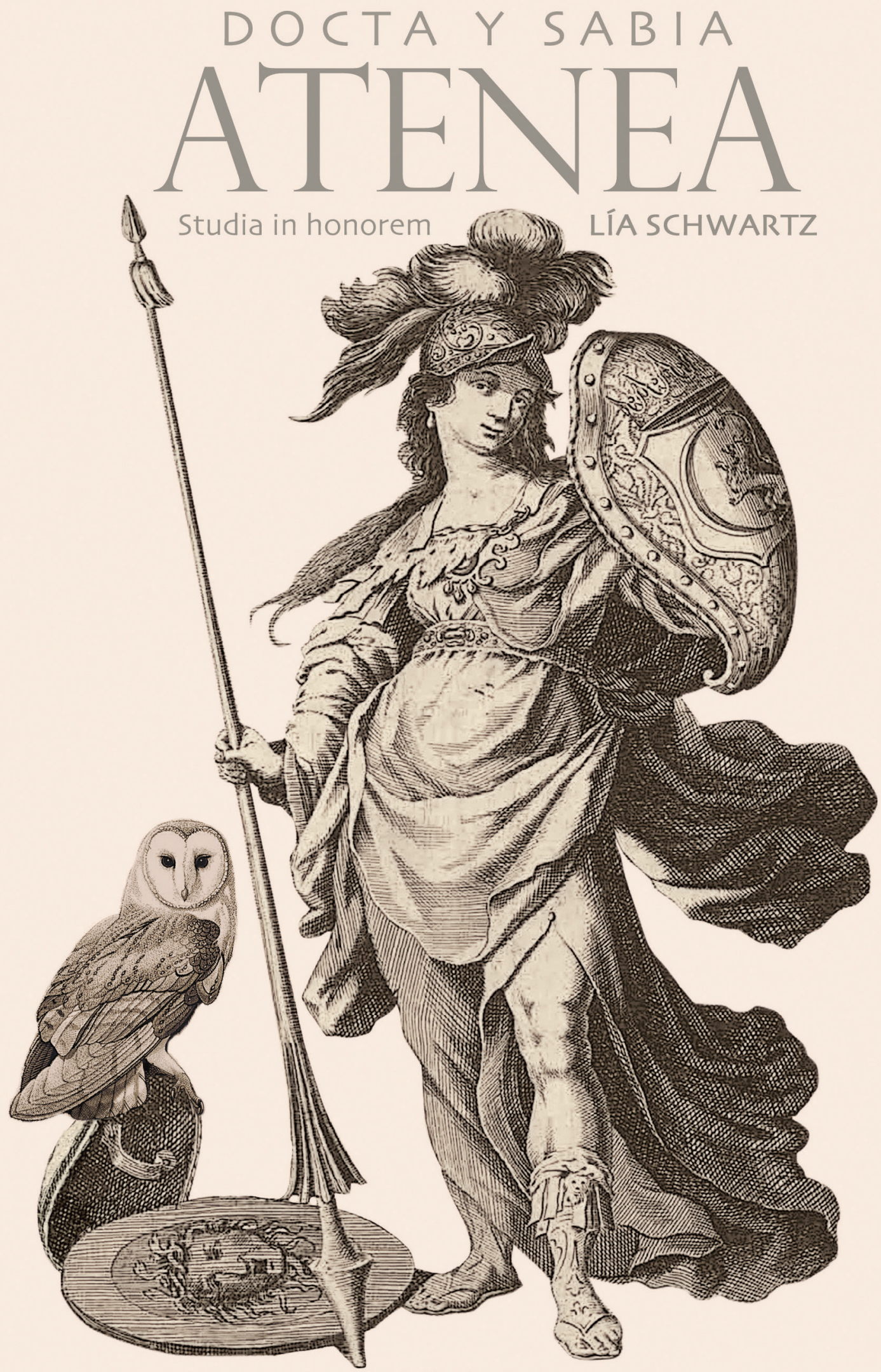

Edición al cuidado de:

SAGRARIO LÓPEZ POZA, NIEVES PENA SUEIRO, MARIANO DE LA CAMPA, ISABEL PÉREZ CUENCA, SUSAN BYRNE Y ALMUDENA VIDORRETA 



\section{DOCTA Y SABIA ATENEA Studia in honorem Lía Schwartz}

Edición al cuidado de:

Sagrario López Poza, Nieves Pena Sueiro, Mariano de la Campa, Isabel Pérez Cuenca, Susan Byrne y Almudena Vidorreta

A Coruña, 2019 

Profesora Lía Schwartz

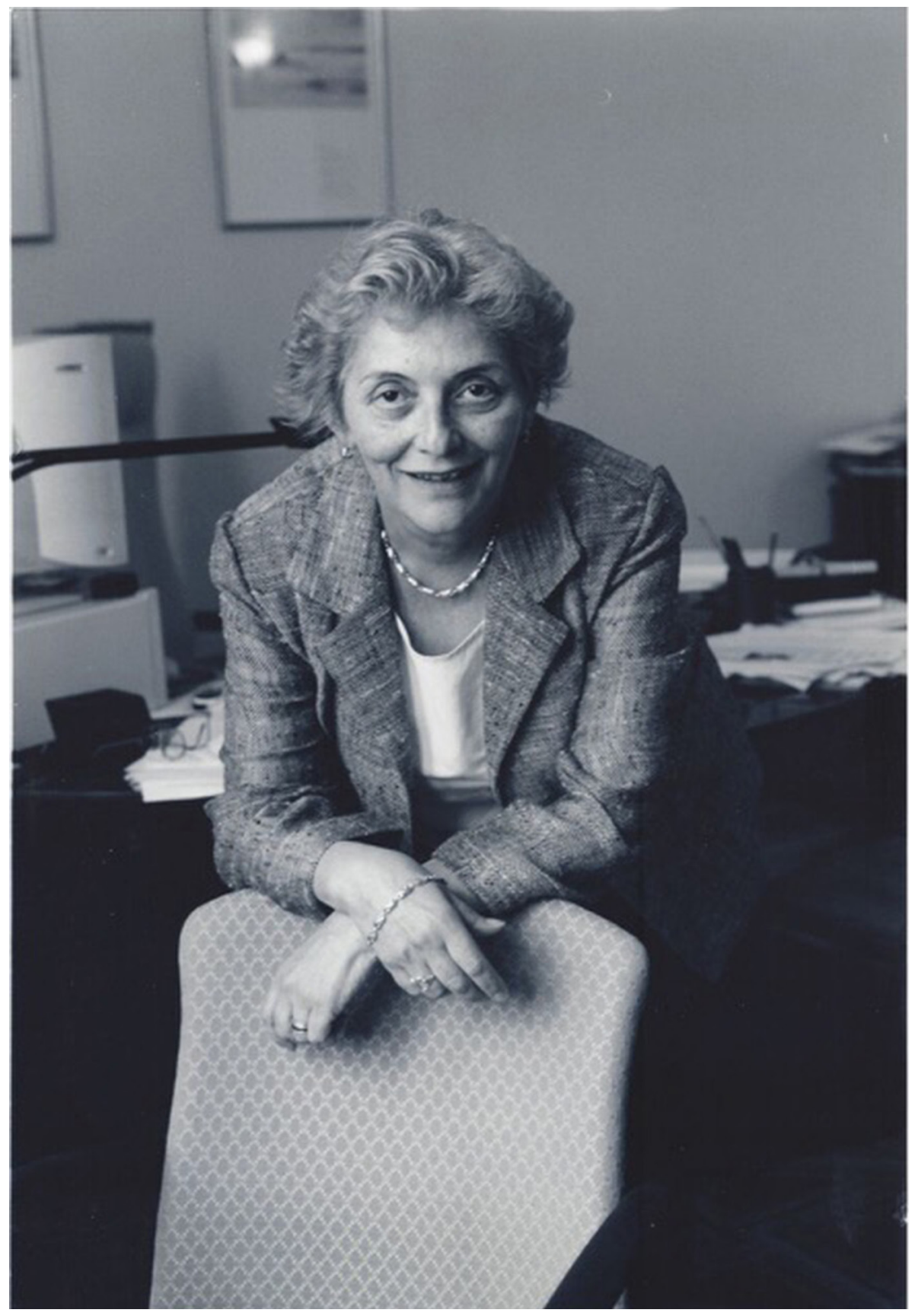


Sagrario López Poza, Nieves Pena Sueiro, Mariano de la Campa, Isabel Pérez Cuenca, Susan Byrne, Almudena Vidorreta (editores)

Docta y sabia Atenea. Studia in honorem Lia Schwartz

N. ${ }^{\circ}$ de páginas: 832

$17 \mathrm{x} 24 \mathrm{~cm}$.

Índice: pp. 7-10

ISBN: 9788497497046

Depósito Legal: C 53-2019

CDU: $821.134 .2(082.2) *$ SCHWARTZ

IBIC: DS | 2ADS | DQ

Editan:

Universidade da Coruña, Servizo de Publicacións

Instituto Universitario "La Corte en Europa" (IULCE), Universidad Autónoma de Madrid

Hispanic Seminary of Medieval Studies (HSMS), New York

Queen Sofía Spanish Institute, New York

Seminario Interdisciplinar para el estudio de la Literatura Áurea Española (SIELAE), Grupo Hispania, Universidade da Coruña

(C) Los autores

(C) De esta edición:

Servizo de Publicacións, Universidade da Coruña

Colección: Homenaxes n. ${ }^{\circ} 14$

Diseño de la cubierta: Paula Lupiáñez (Cirugía Gráfica. Madrid)

Interior: Juan de la Fuente

Impreso en Lugami Artes Gráficas, Betanzos (España)

Printed in Spain 


\section{ÍNDICE}

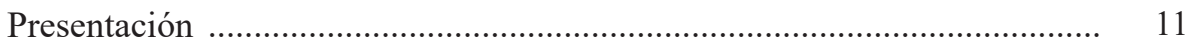

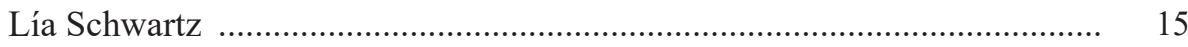

Bibliografía de Lía Schwartz ................................................................. 19

\section{Estudios en homenaje a la profesora Lía Schwartz}

Antonio Azaustre

Notas sobre la filiación en la tradición manuscrita de El alguacil endemoniado

Mercedes Blanco

Para una definición del gongorismo. El caso de Nueva España

69

JAVIER BLASCO

«Salta Pan, Venus baila, Bacho entona»: el campo léxico de la música como vehículo del erotismo en la poesía de los Siglos de Oro

SUSAN BYRNE

La armonía neoplatónica en "A Francisco de Salinas» de fray Luis de León

Mariano de La CAMPa

Poemas de Quevedo en impresos del siglo XVII: Los Romances varios .....

Manuel Ángel Candelas

La poesía española en los manuscritos de la Biblioteca Nazionale di Napoli: noticias y textos

ANTONIO CARREÑo

Lope de Vega: «Rompa ya el silencio el dolor en mí»

Donald CRUickshank

Don Toribio Cuadradillos, «avestruz del amor», and El lindo don Diego (with a note on Quevedo) 
María D'Agostino

Un juego de espejos deformantes. La «representación» del conde de Lemos entre Argensola y Cervantes

TREVOR J. DADSON

«Yo no puedo salir del trabajo de parecer a los portugueses castellano y a los castellanos portugués»: Diego de Silva y Mendoza y la poesía hispanoportuguesa de principios del siglo XVII

Ottavio Di Camillo

Of Roasted Eggs and Other Issues in the Celestina

Aurora EGIDO

Retórica y poética de los afectos en el soneto XIV de Garcilaso 265

Santiago Fernández Mosquera

El vicio de la virtud en Los trabajos de Persiles y Sigismunda 283

Flavia Gherardi \& Pedro Cátedra

El Discorso in difesa della poesia de Gian Ambrogio Biffi en el ámbito de la poética italiana y española

AdRIÁN M. IZqUiERDO

Paráfrasis y experimentación poética en el Anacreón castellano de Quevedo

HILAIRE KALLENDORF

Splitting Hairs or Finding Threads: The Labyrinth as Metaphor for Moral Dilemma in the Comedia

José ENRIQUE LAPLANA

La erudición en el Para todos de Juan Pérez de Montalbán

Begoña LóPEZ Bueno

El Ramillete de las Musas Castellanas (Bibliothèque Mazarine, ms. 4047): un canon literario español en el siglo XVII francés. Primera parte

SAGRARIo LóPez PozA

«Amoris vulnus idem sanat, qui fecit». Notas sobre la fortuna de un topos clásico

ISABEL LOZANO RENIEBLAS

El mal latín del episodio de dos falsos cautivos del Persiles 
Alison Maginn

Rubén Darío's Final Chapter: Archer Milton Huntington and the Hispanic Society

Miguel Martínez

Góngora asiático. Notas sobre poesía filipina inédita del primer Barroco ....

José Martínez MiLlán

Isabel Clara Eugenia, ¿una infanta castellana?

Clayton McCarl

Hacia un modelo para el marcado semántico de los textos marítimos de la época colonial

\section{Juan Montero Delgado}

Un soneto desconocido de Pedro Espinosa a Francisco de Rioja en el ms. Span 56 de la Houghton Library (Universidad de Harvard) 561

Nuria Morgado

Pervivencia del Barroco en la poética de la modernidad: intuiciones y conceptos en el pensamiento literario de Antonio Machado

FRANCISCA MOYA DEL BAÑo

La presencia de Plauto en Quevedo

VALENTINA NIDER

El oro como botín en los poemas de Quevedo sobre Belisario (B-267 e

B-281) y el contexto literario hispano-italiano

ISABEL PÉREZ CUENCA

Francisco de Quevedo y Antonio Sancho Dávila y Toledo Colonna, III marqués de Velada

FERnANDo Plata

El sentido de «barranco» en La Perinola de Quevedo y en otros textos del Siglo de Oro 653

José María Pozuelo Yvancos

Interdiscursividad: cine y literatura en Javier Cercas 671

Augustin Redondo

El tema de la mujer caída de una torre abajo: tradiciones culturales (grecolatinas, bíblicas, folklóricas), creencias religiosas y creaciones cervantinas ... 
MANUEl Rivero RODRÍGUEZ

El conde duque de Olivares, mecenas de la Historia y creador de opinión ... 701

MARIE RoIG Miranda

Los Sueños de Quevedo o cierto tipo de novela 723

Melchora Romanos

Séneca en las Anotaciones de Pedro Díaz de Rivas a los poemas mayores de Góngora

JAVIER SAN JosÉ LeRA

La Política de Dios de Quevedo como comentario bíblico: Política, Biblia y Literatura

LuIs SÁNCHEZ LAÍlLA

Ignacio de Luzán y la musa bucólica

Almudena Vidorreta

Teresa de Jesús, precursora de Gabriela Mistral y Alfonsina Storni

JUAN DiEgo VILA

«con las ansias de la muerte»: El aparato prologal del Persiles como programa estético del estilo tardío cervantino 


\title{
Splitting Hairs or Finding Threads: The Labyrinth as Metaphor for Moral Dilemma in the Comedia
}

\author{
HILAIRE KALLENDORF \\ Texas A\&M University
}

In her magisterial essay «De laberintos: mito y metáfora en textos barrocos. Notas para la historia de su itinerario», Lía Schwartz traces the presence of this classical motif through prose and verse, in both narrative and dramatic works produced during the twilight years of Spain's Golden Age. In this article, she highlights the neo-Stoic philosophical lineage of this topos, which lends itself with remarkable ease to the Christian Humanist synthesis:

La extensa difusión de las teorías neoestoicas en el siglo XVII generó una serie de topoi filosóficos que dialogaban con otras tantas metáforas teológicas en el campo literario del barroco español. Entre ellos se destaca la imagen de la vida o el mundo como edificio laberíntico en el que se encontraba el hombre desde su nacimiento y del que no podía liberarse. (Schwartz, 2013: 833)

She goes on to analyze the appearance of this theme in Gracián, Quevedo, Calderón, Cervantes, and Tirso de Molina, among others, while simultaneously uncovering the classical tradition behind its genealogy. She does this by examining iterations of the myth in such ancient pagan authors as Plutarch, Virgil, and Ovid, along with its continuations and adaptations in the works of later writers like Boccaccio, Natale Conti and Juan Pérez de Moya. She even touches upon patristic figures, namely Saint Ambrose, Saint Gregory, and Saint Jerome, all of whom appropriated the 
labyrinth as a metaphor and endowed it with moralizing connotations. In this essay I propose to go one step further into a realm unexplored by Professor Schwartz: casuistry, or case morality. In doing so I will argue that the labyrinth effectively becomes a lexical marker - a signpost, if you will - to signal the textual presence of casuistical discourse, particularly as that discourse works as a driving force behind the action in early modern Spanish stage plays.

As Professor Schwartz's article also did with her use of the CORDE lexicographical website ${ }^{1}$, this project employs the methods of digital humanities. According to word searches performed using the Teatro Español del Siglo de Oro (TESO) database, distributed by ProQuest, the word «labyrinth» (laberinto) occurs at least 341 times in 204 different comedias and autos sacramentales written by playwrights such as Calderón de la Barca, Guillén de Castro, Miguel de Cervantes, Juan Bautista Diamante, Juan de Matos Fragoso, Agustín Moreto, Juan Pérez de Montalbán, Francisco de Rojas Zorrilla, Juan Ruiz de Alarcón, Tirso de Molina, Lope de Vega, and Antonio Zamora. In some of these plays the word is central to the play's concept, as in Lope de Vega's El laberinto de Creta (1621) or Calderón's El laberinto del mundo (1717); while in other works (like Cervantes's El laberinto de amor [1615]), it appears to be more tangential to the comedia's overarching theme. In almost all cases, however, the presence of this word signals some sort of moral dilemma or ethical quagmire which the characters involved must somehow find their way out of. This essay will make its listeners more attuned to casuistical discourse in the comedias, while at the same time heightening awareness of the interplay of classical and Christian motifs. The resulting synthesis will be demonstrated to fit within established paradigms of Christian Humanism in the Renaissance and Baroque periods in Spain.

This is not the first such 'signpost' or lexical marker I have traced which functions to signal the presence of casuistical discourse in early modern Spanish dramas. In my article "¿Qué he de hacer?”: The Comedia as Casuistry» (Kallendorf, 2004), a version of which was later incorporated into my book Conscience on Stage: The Comedia as Casuistry in Early Modern Spain (Kallendorf, 2007), I was the first scholar to notice the almost ubiquitous presence of the catch phrase ‘¿Qué he de hacer?' ('What

1 The CORDE database - Corpus Diacrónico del Español - is a project of the Real Academia Española. It can be consulted online at $<$ http://corpus.rae.es/cordenet.html $>$. 
should I do?'), repeated in dramatic soliloquies or dialogues as characters pondered ethical dilemmas and sought one another's advice. Ultimately I was able to make the case for establishing a poetics of the comedia as a genre which is rooted in casuistry. This essay is an extension of that work. In exploring this trope more in depth, I have benefitted enormously from the remarkable study by Penelope Reed Doob, The Idea of the Labyrinth from Classical Antiquity through the Middle Ages (Doob, 1990). Her book does not extend into the Renaissance or Baroque periods, but some of her insights have proven invaluable nonetheless. This piece is also an homage to Professor Schwartz, to whom I am grateful, and a continuation of her own work on the maze as literary trope. We stand on the shoulders of giants. Now, into the labyrinth...

Labyrinths in early modern Spanish stage plays often appear as metaphors for the world, love, the soul, or even life itself. In the case of love, we find lines such as «no veo la hora de salir de este ciego laberinto de amor, donde a cada paso luces toco, y sombras» (Calderón, Cada uno para sí: Jornada 2) $)^{2}$. This 'labyrinthine' type of love is sophisticated and exotic, more suitable for royals than for plebeians with pedestrian affections:

en las personas Reales

no ha de ser amor plebeyo, sino raro, y peregrino

laberinto, encantamiento, y como el amor de Psique que a oscuras durmió gran tiempo con el niño amor su esposo.

(Lope de Vega, Quien más no puede: Acto 2)

From a more spiritualized angle, the labyrinth can also present a picture of the soul. This word choice normally portrays the soul as anguished, for

2 N.B. Unless otherwise indicated, for all plays cited in the text of this essay, citations are to the digitalized versions available in the Teatro Español del Siglo de Oro [TESO] database, distributed by ProQuest: <http://teso.chadwyck.com>. Archaic spellings have been modernized. 
the paths of this labyrinth become hopelessly tangled: «al laberinto llegué donde las almas se enredan» (Lope de Vega, Guardar, y guardarse: Acto 1). In this internal labyrinth, the soul is held prisoner: "salí del laberinto donde el alma presa estaba» (Lope de Vega, La pastoral de Jacinto: Acto $3)^{3}$. These lines tend to be fairly absolute in their bleakness: all the soul is a labyrinth; no part of it is not convoluted. For example, «si es toda el alma laberinto, ¿cómo podrán salir cuidados de ella?» (Lope de Vega, La prueba de los ingenios: Acto 3). The soul itself cannot escape the labyrinth, nor can «cares» — preoccupations, worries, anxieties — be exorcized from it.

Lest we become too ethereal and other-worldly, this labyrinth 'syndrome' includes the body as well; for example, when a character declares, «en tal desasosiego, ni el alma y cuerpo enredaré en laberinto tan ciego» (Lope de Vega, Roma abrasada: Acto 1). An enigmatic person can also be described as a labyrinth, as when one character says to another: "para mi desdicha has sido un Enigma con sentido, un Laberinto con Alma» (Calderón, El castillo de Lindabridis: Jornada 1). In fact, the labyrinth turns into a metaphor for corporeal life itself: «intricados Caminos de la Humana Vida, que es un confuso Laberinto» (Calderón, A tu prójimo como a ti). By extension, the labyrinth came to represent a pilgrimage, to the point that believers would actually tread labyrinth designs on cathedral pavements —often on their knees - as a sort of substitute pilgrimage. Doob unpacks the faulty syllogism inherent in this analogy: «As classical and early Christian writings show, life can be compared to a labyrinthine journey; since life may also be compared to a pilgrimage, the argument would go, a pilgrimage must be a labyrinth» (Doob, 1990: 120-121). Faulty logic or not, this is how classical myth was reinterpreted in later times.

The most common adjectives used to describe these theatrical labyrinths are «dark», «deep», «confusing», and «blind». The labyrinth is dark: «Yo lo veré presto, para que salgamos de este oscuro laberinto» (Calderón, No siempre lo peor es cierto: Jornada 3). Doob comments on this feature: «Darkness and noise, concomitants of chaos, recur in later labyrinths» (Doob, 1990: 25).

3 Doob explicates this part of the classical myth's later trajectory: «The fact that Minos the law-giver ordered the imprisonment of the Minotaur supports later associations of the maze with just imprisonment. These points may well have influenced later redactors of a narrowly moral bent to consider the labyrinth as prison for monstrous cupidity, an image of sin, or hell itself» (Doob, 1990: 35). 
It is also deep, as in «O laberinto profundo, si más se entra más se enreda» (Lope de Vega, El vaquero de Morana: Acto 1). Of course, it is confusing: «me forman los pensamientos un confuso laberinto» (Alarcón, Los favores del mundo: Acto 1). However, Doob observes that the labyrinth is confusing only to the unfortunate wanderer who happens to be trapped inside. She notices

one major paradox inherent in the labyrinth image: its status as simultaneously a great and complex work of art and a frightening and confusing place of interminable wandering - the labyrinth as order and as chaos, depending on the observer's knowledge and perspective. (Doob, 1990: 18)

Perhaps cognizant of this perspectival element, one stage character holds out hope to another that «Presto saldrás de ese laberinto de dudas, y confusiones» (Calderón, Las cadenas del demonio: Jornada 2). The goal with any labyrinth is to «rescatar mi entendimiento de la confusión que paso. ¡Qué intrincado laberinto es en el que voy entrando!» (Calderón, Los dos amantes del cielo: Jornada 1). Doob comments on these as well as additional features of the labyrinths she studies:

Most inextricable labyrinths carry heavy moral freight. Their structural errores, whether traps laid by devils and heretics or confusions created by maze-walkers themselves, are inescapable unless special aid is granted. Prisons whose darkness and obscurity correspond to the moral or intellectual blindness of their inhabitants, they afford no sight of a goal, no sense of pattern, and they lead almost inevitably to chaos, death, and damnation. Thus they become useful signs for everything constricting and imprisoning (death, life, sin, heresy, pagan philosophy). (Doob, 1990: 82)

With all of these possible connotations, the intricacy of the labyrinth is enough to make one blind, although by way of poetic transference the labyrinth itself is described with this adjective: «No te entiendo, amor me saque de tan ciego laberinto» (Calderón, Cómo se comunican dos estrellas contrarias: Jornada 2). The labyrinth is particularly dark or blindnessinducing when love has placed one there, as opposed to love being the force that can show the way out: «Ya en el ciego laberinto te metió el amor cruel, ya no puedes salir de él». (Cervantes, El laberinto de amor: Jornada 1). These words are enough to send a chill down one's spine, making the 
listener or audience feel claustrophobic. This Renaissance manifestation of blindness in connection to labyrinths is different from its medieval version, studied by Doob, in which blindness refers not to romantic love but instead to doctrinal heresy: «the maze's traditional darkness contributes to its inextricability, echoing the blindness of false believers» (Doob, 1990: 76). Often a stage reference to the «blind» labyrinth will be combined with the other catch phrase I have studied, «What will I / should I do?», as in the example «¿Qué haré en tan ciego abismo, humano laberinto de mí mismo?» (Calderón, La dama duende: Jornada 3). This was one of the main lines which caught my attention when working on some variations of that first catch phrase I noticed as indicative of the presence of casuistical discourse («¿Qué he de hacer?»).

The answer to the question «What should I do?» in the context of labyrinths is, undoubtedly: try to find a way out. In the process of navigating the twists and turns of a maze, often one bodily sense is substituted for another. One must use ears to hear where eyes cannot see:

\author{
¿Quién eres, que con vendada \\ vista discurres a tino \\ las enmarañadas sendas \\ de este humano Laberinto; \\ de Oídos, y Ojos trocados \\ los naturales oficios, \\ pues lo que no ven los Ojos, \\ quieres ver con los Oídos?
}

(Calderón, La lepra de Constantino, auto sacramental)

The staging of this scene might have been enhanced by the use of specific props such as a blindfold. Labyrinthine discourse often leads to funny playing with other myths, such as the one that says love-personified by the child god Cupid - is blind: «Niño Dios, aunque eres ciego, ¡dame luz en el confuso laberinto en que me veo!» (Zamora, Duendes son alcahuetes, alias el foleto, segunda parte: Acto 1).

In addition to humor, another dramatic element invoked by the use of the labyrinth is wonder. In the Age of Discovery, a classically-infused vocabulary was often deployed in a rhetoric of admiratio (Greenblatt, 1991; Grafton, 1995). In the context of labyrinths, we often encounter 
provocative words ${ }^{4}$ such as «new» and «strange»: «¿Hay tan nuevo laberinto?» and «¿Habrá sucedido a ninguno tan extraño laberinto como a mí?» (Matos Fragoso, La tía de la menor, Jornada 2). The labyrinth as theatrical space is shrouded in mystery and miracles: «¿Qué intrincado laberinto de milagros, de misterios es éste?» (Calderón, Los dos amantes del cielo: Jornada 1) and, in a variant on our previously-noted catch phrase, "¿Qué he de decir? Milagro será salir de este laberinto» (Guillén de Castro, La fuerza de la sangre: Jornada 3). With broad brush strokes, we begin to fill in the sketch or complete the picture of how labyrinths form the very stuff of the neo-Aristotelian legitimate marvelous. As I noted in my first book, Exorcism and Its Texts, with regard to scenes of demonic possession and exorcism incorporated into literature:

[F]ar and away the most influential theories about the marvellous to be received by the early modern period from antiquity were those of the moderate Aristotle. The neo-Aristotelians insisted on the inclusion of the marvellous only if it was tempered by the principle of verisimilitude. Mazzoni lists thirty-four ways to make the marvellous credible... . NeoAristotelian interest in the marvellous was not limited to Italy alone... . Alonso López Pinciano describes poems that do not include the marvellous as 'cold dreams'. (Kallendorf, 2003: 190-191)

As part of the classical tradition inherited by Renaissance humanists, the labyrinth would have been the perfect vehicle for conveying plausible or credible — but still sensational-admiratio.

The polar opposite of marvelous and wonderful is, of course, horror. Doob comments on this dichotomy in reference to the labyrinth: «objectively, as artifact, it is a magnificent design; subjectively, as experience, a potential chamber of horrors» (Doob, 1990: 24). The

4 A similar word which often occurs in the context of labyrinths in English, but is not found in early modern Spanish drama because of the language in which it is written, is 'amazed'. As Doob explicates this powerful linguistic association, «How did it happen that an Old English word describing a state of mind came to signify a labyrinth? The answer must lie in the confusion and bewilderment common to both: if a mazed man is confused or deluded and a labyrinth confuses and deceives, then a labyrinth is a maze. Maze comes to signify labyrinth by a kind of metonymy, the effect giving its name to the cause» (Doob, 1990: 98-99). 
labyrinth is not only a wonder-inducing ethereal space of magic and mystery, but also synonymous with prison and a grave or tomb $b^{5}$ where one is buried alive: «Oscuro laberinto, cárcel fuerte, sepultura de vivos afligidos» (Lope de Vega, Amar sin saber a quién: Acto 1). The specific fear of being buried alive may stem from the romancero tradition, which includes a ballad about the last Visigothic king, Rodrigo, being buried alive with a serpent who gnaws on his genitals in punishment for losing Spain and 'inviting' the Muslim invasion through his lust for La Cava'; but it also resonates with the short story La inocencia castigada by María de Zayas, whose heroine is shut up inside the chimney of her house for six years by her relatives (Zayas, 1989: 298-299). Elena del Río Parra has studied these and other incidences of this phenomenon - including a preColumbian exhibit I saw in the Museo del Hombre Dominicano in Santo Domingo, Dominican Republic in 1992 of a Taíno cacique's wife who was forcibly buried alive with her dead husband - in her article «He Has No Pulse»: Typologies of the Fear of Being Buried Alive in Preindustrial Spain» (Del Río Parra, 2011).

Labyrinths are also deployed by dramatists to plumb the depths of human psychology, specifically melancholy or depression: «melancólica estoy, que a nada salida doy, que está un laberinto en mí» (Tirso de Molina, Los amantes de Teruel: Jornada 2). Doob confirms in this regard that «most labyrinth metaphors stressing inextricability involve a subjective or psychological component» (Doob, 1990: 56). Wandering the labyrinth long enough could even lead to madness: «Perdido el tino por este laberinto voy errado» (Lope de Vega, La boba para los otros, y discreta para si: Acto 1). The despair of this sensation is expressed aptly in the lines:

Oscuro laberinto, caos confuso, donde tanto la razón se enreda, que no hay hilo y industria con que pueda salir a luz.

(Lope de Vega, La fortuna merecida: Acto 1)

5 On the maze as a tomb, see Doob, 1990: 25.

6 «Penitencia del rey don Rodrigo» (1547), digitalized in the Pan-Hispanic Ballad Project (<http://depts.washington.edu/hisprom $>$ ). For commentary on this ballad in the context of the sin of lust, see Kallendorf, 2013: 273-274, note 63. 
At this point we must pause to clarify that the use of the labyrinth as dramatic metaphor is by no means value-neutral. It has clear implications for morality. When one loses one's way, one strays into Vice?:

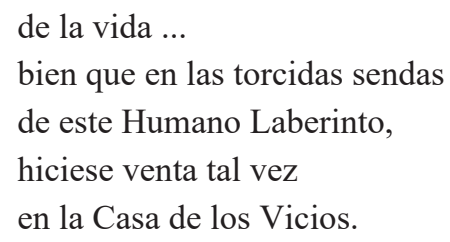

(Calderón, El año santo en Madrid, auto sacramental)

Passages such as this one place the labyrinth squarely (as it were-although labyrinths can also be round) within the casuistical discourse of doubt and dilemma, as in the case of a character «quien por huir de una duda ha dado en un laberinto» (Juan de Matos Fragoso, Callar siempre es lo mejor: Jornada 2). These stage personae ask each other questions such as, « ¿Hay tan raro laberinto de duda? Sin juicio estoy» (Pérez de Montalbán, Como amante, y como honrada: Jornada 2). The appearance of a labyrinth in a play's dialogue should signal to the audience suspicion and caution: «que por más que solicito borrar aquesta sospecha, salir de este laberinto, ni lo afirmo cauteloso, ni lo niego discursivo» (Moreto, Hacer del contrario amigo: Jornada 1).

As Doob shrewdly points out, «the presence of true and false paths in the multicursal maze may suggest the importance of correct moral or intellectual choice within a confusing world» (Doob, 1990: 5). But the only way to choose rightly is often to choose wrongly first, and then learn from that mistake. We might think of such intermediate steps as trial and error, or a succession of approximations.

In fact, what is a maze if not a series of choices? In the following passage, Doob describes the physical sensation of walking through a maze, but she might just as well be explaining the casuistical process of reasoning through an ethical decision:

7 As Penelope Reed Doob explains it, in the moral realm, «narrative context tends to equate the structural windings or errores of the maze with moral error... [E]rrors define the territory—without errores, there's no labyrinth» (Doob, 1990: 7, xv). She later clarifies that «wandering in itself suggests moral culpability: errors, strayings from the straight and narrow» (Doob, 1990: 50). 
[A]s the term «multicursal» suggests, this kind of maze is a series of choices between paths. Classical writers knew a great deal about the bivium, the Herculean or Pythagorean choice represented by the letter $Y$, with one road leading gently to pleasure and the other austerely to virtue; Christian writers would lend the image biblical authority by referring to Matthew 7:13-14, the choice between the broad path to destruction and the narrow way to life... The multicursal labyrinth is even more rigorous, however, for it does not consist of a single crucial choice; rather, it incorporates an extended series of bivia, an array of choices. It embodies frequent testing and repeated confrontations, with no apparent end to the struggle until the goal or the entry is achieved. Hence this type of maze is a perfect symbol of intellectual and moral difficulty... The characteristic quality of movement through such a maze is halting, episodic, with each fork or alternative requiring a pause for thought and decision. The direction of movement is constantly shifting... [A] maze-walker may lose confidence, retrace his (or her) steps, take another path, right or wrong. The essence of the maze experience is confusion, doubt, and frustration as one ambiguity succeeds another. (Doob, 1990: 46)

The labyrinth becomes such a recognized trope in casuistical monologues in the comedias that we even find metatheatrical commentary built into the lines of some of these plays, as with the lines, «Estrellas, con todos los requisitos de soliloquio furioso, ¿saldré de este laberinto?» (Calderón, El postrer duelo de España: Jornada 2). Here a character, in an ironical aside, voices metatheatrical commentary on his own performance of a «furious» soliloquy. These plays containing labyrinths also voice more general metaliterary commentary such as a critique of Baroque conceptismo: «Y el confuso laberinto de conceptos fondo en raso» (Diamante, Amor es sangre, y no puede engañarse: Jornada 1) or philosophy: «¿Dónde estamos? ¿Qué filosofía es ésa? ¿En qué laberinto he dado? ¿Cómo me he metido aquí?» (Lope de Vega, El villano en su rincón: Acto 2). The labyrinth came to be synonymous with highly elaborate discourse: «no es baja frase, puesto que es frase de laberinto» (Calderón, Darlo todo, y no dar nada: Jornada 3). These phrases call to mind contemporaneous critiques of Baroque literary movements like culteranismo or gongorismo, which were deemed by their opponents to be overly laden with artificial, obscure constructions. As Doob reminds us, «the term 'labyrinth' is most commonly applied pejoratively to failed art, art that is too complex for its intended audience and purpose» (Doob, 1990: 7). 
In addition to general metaliterariness, labyrinths could be overtly metatheatrical. Sometimes they are conflated with actual stage directions where characters find themselves trapped in a labyrinth-like space: «Y con estas ocasiones es mi casa de inquieta un laberinto de Creta, y es un caos de confusiones» (Guillén de Castro, Los enemigos hermanos: Jornada 1$)^{8}$. The ultimate instance of this spatial correspondence to the subject matter occurs when a character finds himself not in his own, but instead in his enemy's house:

\author{
¿Habráse algún hombre visto \\ de cuantos hasta hoy nacieron, \\ en más ciego laberinto? \\ Las cuchilladas de anoche \\ en mi casa, el desafío \\ de hoy, y el ver aquí a Leonor, \\ evidencias son, no indicios \\ de que ella es causa de todo: \\ y por último delirio \\ de mi fortuna, me veo, \\ habiendo hasta aquí venido \\ por un amigo, encerrado \\ en casa de un enemigo. \\ Pero pues es imposible \\ la puerta abrir, y aquí miro \\ una ventana sin reja, \\ arrojarme determino \\ por ella, y en seguimiento \\ de mi siempre honor invicto, \\ hacer estragos, portentos, \\ escándalos, y prodigios. \\ Ea corazón, no temas \\ este breve precipicio, \\ que mayor caída has dado, \\ pues la mayor siempre ha sido \\ el verse caer un hombre \\ del estado de sí mismo.
}

(Calderón, Los empeños de un acaso: Jornada 2)

8 This example actually combines the trope of the labyrinth with another casuistical code word, ocasión, about which see the pioneering study by Fernando Plata (Plata, 2008). 
And he throws himself out the window... .

At other times the labyrinth can describe not just a house, but by extension an entire city of maze-like narrow streets, most notably the rabbits' warren which is (even to this day) the city of Seville: «En Sevilla digo, aquella agradable muchedumbre; aquel laberinto afable de hermosuras, y de lustres» (Diamante, El defensor del Peñón: Jornada 3). As Enrique García Santo-Tomás explains in his essay «Civic Ritual, Urban Life» in my edited volume Companion to the Spanish Renaissance,

cities like Seville and Madrid were depicted as the symbol of the cosmos and in the shape of a labyrinth, as a site of hidden and covered experiences through the portrayal of flirtatious lads and damsels (escondidos and tapadas), sometimes as a treacherous ocean, sometimes as a mundo abreviado that captured the complexity and variety of nature. (SantoTomás, 2018: 285)

Since it would have been impossible to recreate an entire city on stage, the use of the evocative word «labyrinth» could serve as a substitute by instead summoning a mental picture of dark alleyways in which real-life versions of the capa y espada (cloak-and-dagger) plays were known to have been enacted ${ }^{9}$.

In fact, it might not be too great a stretch to see the labyrinth as a metaphor for the comedia as an art form which is known for what Doob might call «digressiveness ... detours, delays, and diversions» (Doob, 1990: 54). In the conclusion to my book Conscience on Stage, I speculated that casuistical discourse serves as the «engine» driving the action of most early modern Spanish comedias, in part because it works as an agent of Derridian deferral and dilatio:

The function of casuistry's trace in the comedia is to suspend the action, prolonging the process of resolution in a Derridian logic of deferral... .

9 The labyrinth as metaphor for a city occurs in earlier literature as well; as Doob explains, «[t]he maze-city equation, familiar in turf and stone labyrinths, often occurs in... manuscripts... Usually the city involved is Jericho, whose special relationship to the labyrinth we have... discussed, but Constantinople is also depicted as a maze» (Doob, 1990: 138). 
Casuistry serves as the missing link between theology and rhetoric by 'filling in the blanks' between religious doctrine and practice. Every decision on how to implement religious belief in the course of everyday life (by definition) involves ethical reasoning. It is this type of ethical reasoning which ... becomes an obsession for comedia characters and their authors and thus provides a glimpse of one of the major preoccupations of early modern Spanish society... . [C]asuistry is enlisted in the service of a teleology of deferral to prolong the action, increase suspense, and hold the interest of the audience. (Kallendorf, 2007: 193-194, 198)

If we accept the premise of differrance as crucial to the comedia's artistic enterprise, it should not surprise us to find images such as the labyrinth deployed to serve a similar theatrical purpose.

The development of this casuistical linguistic register was not limited to only the actual structure of the labyrinth itself. Various casuistical identifications or interpretations recur frequently for other elements of the myth as well, such as the minotaur, King Minos, Daedalus, Theseus, Ariadna, and even the famous thread. Naturally, the Minotaur is identified with cruelty in the realm of human behavior, such as when it is said of the imprisoned Segismundo that «humana necesidad le enseña a tener crueldad, monstruo de su laberinto» (Calderón, La vida es sueño: Acto 1). Other human qualities critiqued through this discourse are betrayal and deception, as when a Queen exclaims:

Gracias a Dios que he salido de aquel laberinto extraño, donde la traición, y engaño trocando el traje, y vestido con la verdad desterrada vende el vidrio por cristal, o carga del trono Real del ignorante adorada.

(Tirso de Molina, La prudencia en la mujer: Jornada 3)

In a similar instance, another character declares emphatically, «entré en este laberinto por la puerta del engaño». (Lope de Vega, El servir con mala estrella: Acto 3) 
In an additional Baroque twist, the Minotaur is identified with Time, which devours all:

\author{
vi dentro del laberinto, \\ en forma de Minotauro \\ al tiempo, a quien bendiciones \\ iban los hombres echando, \\ a quien la suerte cabía \\ de morir y sustentarlo.
}

(Lope de Vega, El servir con mala estrella: Acto 3)

Here Luck or Fortune is the executioner or verdugo who feeds men to the Minotaur of Time, who gnaws on them as mercilessly as Saturn devouring his son in Goya's grim painting, now held at the Prado Museum.

Not all of these identifications with elements of the myth are so serious or philosophically profound, however. Some are just downright humorous. In the hands of a magician like Lope de Vega, King Minos becomes an average pimp: «Dios, que Felisardo no haya sido tu alcahuete, que en laberinto te mete, de donde mal fin aguardo» (Lope de Vega, Los amantes sin amor: Acto 2). Daedalus is Love: «Que al laberinto ha de hallar entrada amor: que amor es grande arquitecto» (Lope de Vega, La prueba de los ingenios: Acto 3). Theseus is identified with Thought: «mis ojos cual mis deseos, mis pensamientos Teseos de este laberinto extraño» (Tirso de Molina, Averígüelo Vargas: Jornada 1). Or alternatively, Theseus is Reason, as when Clotaldo in Calderón's La vida es sueño exclaims, «Escucha, aguarda, detente, ¿qué confuso laberinto es éste, donde no puede hallar la razón el hilo? (Calderón, La vida es sueño: Acto 1). Ariadne is ingenuity: «ingenio no le diera el hilo de oro de aquel Laberinto ciego» (Lope de Vega, Las mujeres sin hombres: Acto 2). (Ingenious though she was, however, her cleverness did not prevent the ungrateful Theseus from abandoning her in favor of her sister Phaedra.) Or in some variations, Ariadne is identified with prayer, as in Agustín Moreto's hagiographical drama Santa Rosa del Perú: «tus virtudes admiro, sáqueme tu intercesión de este ciego laberinto» (Moreto, Santa Rosa del Perú: Jornada 2).

In a considerably less lofty, more secular interpretation, Ariadne's golden thread becomes money to pay bribes: «pues en casos semejantes para Teseos amantes hay laberinto en mi cueva, que ha de dar con mil sobornos» (Tirso de Molina, Por el sótano y el torno: Jornada 3). For the 
cynical Lope de Vega seeking patronage, the only way out of the labyrinth is quite literally a thread of gold. As the gracioso Fineo in El laberinto de Creta laments,

Estoy por entrar. ¿Qué haré?

Mas que no he de acertar temo, que me falta el hilo de oro;

oro me falta, no puedo, porque monstruo de mujer sin oro, es cosa de cuentos; aun en negocios de acá, ni acertamos, ni podemos, en faltando el hilo de oro, que es con que se sale de ellos.

(Lope de Vega, El laberinto de Creta: Acto 2, p. 73)

Lope echoes this rhetoric in the dedication of his play to the lady «Tisbe Fénix» in Seville, obviously a literary code name for a textually veiled patroness. In the dedication he remarks,

Y hame venido bien el de la fábula, pues tengo de vivir en esperanza y silencio hasta que Vm. se digne de hacerme este favor, y yo me libre de tanta oscuridad a la luz de su conocimiento, con seguridad de no ser ingrato al hilo de oro. (Lope de Vega, dedication preceding El laberinto de Creta: 54)

In this instance financial gain, or interés, trumps morality as greed wins out in the nascent capitalism starting to take hold in early modern Spanish society. Lope might actually have derived this image from Petrarch, who - in his letters - literalizes the classical imagery of Ariadne's 'golden' thread to decry the avarice which, even in the early Renaissance, already was overpowering the loftier ideals of Italian civic humanism:

There is only one hope of salvation here, gold. Gold placates the savage king and overcomes the frightful monster; the guiding cord is woven of gold; gold reveals the forbidding doorway, shatters the bars and stones, bribes the stern doorkeeper, and opens the gates of heaven. What else? Christ is sold for gold. (Petrarch, 1973: 72-73, cited in Doob, 1990: 159) 
His cynicism is disturbing, especially when we consider that he was writing a full two centuries before Lope even picked up his pen.

No matter what these «threads» through the labyrinth are — particularly when they are as tenuous as a lady's favor or a nobleman's patronage- all too often, they break. Don Felipe says, «Yo estoy en un laberinto, donde los hilos se quiebran, porque en efecto son hilos» (Lope de Vega, El sembrar en buena tierra: Acto 2). The key elements here are fragility, ephemerality, and Baroque desengaño. As explicated by Penelope Reed Doob, who began her book with these words but did not seem to grasp that these elements are more characteristic of later times than of the medieval period:

Ancient and medieval labyrinths or mazes ... are characteristically double. They are full of ambiguity, their circuitous design prescribes a constant doubling back .... They presume a double perspective: maze-treaders, whose vision ahead and behind is severely constricted and fragmented, suffer confusion, whereas maze-viewers who see the pattern whole, from above or in a diagram, are dazzled by its complex artistry. What you see depends on where you stand ... . [A]t one and the same time, labyrinths are single $\ldots$ and double: they simultaneously incorporate order and disorder, clarity and confusion, unity and multiplicity, artistry and chaos... . Our perception of labyrinths is thus intrinsically unstable: change your perspective and the labyrinth seems to change... . [L]abyrinths are convertible and relative: what you see and feel and understand one moment can shift completely the next like a reversible figure, an optical illusion. Thus mazes encode the very principle of doubleness, contrariety, paradox, concordia discors. (Doob, 1990: 1-2)

These features of the labyrinth become even more heightened, in the case of early modern Spanish stage plays, by Baroque realities such as the decline of Spain's empire and the bankruptcy of the state.

Inevitably, we reach a moment when suddenly, the dreamlike experience of wandering the labyrinth converts into nightmare: what if there is actually no way out? As Doob follows this logic,

Uncertainty may be heightened in that the maze-walker without a guide cannot know until reaching the end that the chosen path is correct; indeed, he or she cannot even be sure there is an end or center. The multicursal 
maze is dangerous even if no minotaur is lurking, for one risks getting lost and remaining perpetually imprisoned; in such a maze one may find no solution, no center, no exit. (Doob, 1990: 46-47)

For postmodern readers, these sensations sound eerily familiar; as described by Irish poet W.B. Yeats in «The Second Coming»,

Things fall apart; the centre cannot hold;

Mere anarchy is loosed upon the world.

(Yeats, 1997: 68)

But perhaps we get ahead of ourselves. Early modern playwrights and theater-goers could not possibly have been familiar, as Yeats was, with the horrors of the First World War. Even so, they — or the leaders of their society, to be more fair - were the originators of notorious injustices such as colonial conquest and genocide. Perhaps postmoderns don't have a monopoly on fragmentation and wandering after all.

So what are we to make of all of this? Ultimately Doob concludes -and again, this is surprising for a book which theoretically ends with the medieval period - that the multicursal maze highlights the role of the individual and his moral agency (Doob, 1990: 47). She explains:

$[\mathrm{H}] \mathrm{e}$ controls his passage through the maze by his ability to choose and perhaps by memory, and however puzzled and despairing he may be, his fate is as much the result of his (ab)use of free will as it is a consequence of the architect's devious design... . The multicursal maze leaves most choices to the wanderer, and consequently it emphasizes an individual's responsibility for his own fate. (Doob, 1990: 47-48)

I would like to argue that the function of the labyrinth in the comedia is, similarly, to highlight the role of the individual who is faced with moral choices or must find his or her way out of an ethical dilemma. In this sense 
-with apologies to Professor Schwartz- I find the labyrinth to be more quintessentially a Renaissance than a Baroque trope. This finding confirms my conclusion in Sins of the Fathers that Maravall's interpretation of Baroque theater as pertaining to a larger phenomenon he called «guided culture» (una cultura dirigida) (Maravall, 1972) must be re-evaluated, if not discarded altogether (Kallendorf, 2013: 205). My book examined the resurrection of the Decalogue as a newly-invigorated paradigm for morality in the wake of the Council of Trent. The Decalogue, in turn, promoted a more individual - as opposed to a collective, or community-orientedrelationship with God than did the more communal paradigm afforded by its opposing taxonomy, that of the Seven Deadly Sins.

The solitariness of the wanderer in the labyrinth, like the protagonist of Góngora's Soledades, affirms a certain Renaissance salience of the individual. It is my hope that, like with the elaborate labyrinth mosaics inlaid in the pavements of countless European cathedrals, this essay has contributed one small piece to that puzzle.

\section{BIBLIOGRAPHY}

N.B. Unless otherwise indicated, for all plays cited in the text of this essay, citations are to the digitalized versions available in the Teatro Español del Siglo de Oro [TESO] database, distributed by ProQuest: <http://teso.chadwyck.com>.

Calderón de la Barca, Pedro, «El laberinto del mundo, auto sacramental», in Pedro Pando y Mier (ed.), Autos sacramentales, alegóricos y historiales del insigne poeta español don Pedro Calderón de la Barca, Madrid, Manuel Ruiz de Murga, 1717, Tomo VI, pp. 395-432.

Cervantes, Miguel de, El laberinto de amor, in Florencio Sevilla Arroyo and Antonio Rey Hazas (eds.), Teatro completo, Barcelona, Planeta, 1987, pp. 457-542.

Corpus Diacrónico del Español database [CORDE], Real Academia Española, 2018, accessible online: $<$ http://corpus.rae.es/cordenet.html> [consulted 15.7.2018].

Del Río Parra, Elena, «"He Has No Pulse”: Typologies of the Fear of Being Buried Alive in Preindustrial Spain», South Atlantic Review, 76.3 (2011), pp. 129-150.

Doob, Penelope Reed, The Idea of the Labyrinth from Classical Antiquity through the Middle Ages, Ithaca, Cornell University Press, 1990. 
García Santo-Tomás, Enrique, «Civic Ritual, Urban Life», in Hilaire Kallendorf (ed.), A Companion to the Spanish Renaissance, Leiden, Brill, 2018, pp. 277-292.

Grafton, Anthony, New Worlds, Ancient Texts: The Power of Tradition and the Shock of Discovery, Cambridge, MA, Harvard University Press, 1995.

Greenblatt, Stephen, Marvelous Possessions: The Wonder of the New World, Chicago, University of Chicago Press, 1991.

Hocke, G.R., «Kasuistik und Laxismus», in Die Welt als Labyrinth: Manierismus in der europäischen Kunst und Literatur, Hamburg, Rowohlt, 1991.

Kallendorf, Hilaire, «Liturgy in Literature, or Early Modern Literary Theory and the Christian Legitimate Marvellous», in Exorcism and Its Texts: Subjectivity in Early Modern Literature of England and Spain, Toronto, University of Toronto Press, 2003, pp. 184-199.

Kallendorf, Hilaire, "¿Qué he de hacer?”: The Comedia as Casuistry», Romanic Review, 95.3 (2004), pp. 327-259.

Kallendorf, Hilaire, «Wave Imagery, Blindness, and Labyrinths», Conscience on Stage: The Comedia as Casuistry in Early Modern Spain, Toronto, University of Toronto Press, 2007, pp. 118-123.

Kallendorf, Hilaire, Sins of the Fathers: Moral Economies in Early Modern Spain, Toronto, University of Toronto Press, 2013.

Lope de Vega, Félix, El laberinto de Creta, in Marcelino Menéndez Pelayo (ed.), Obras de Lope de Vega, Vol. XIV: Comedias mitológicas y comedias históricas de asunto extranjero, Madrid, Atlas, 1966, pp. 53-98.

Maravall, José Antonio, Teatro y literatura en la sociedad barroca, Madrid, Seminarios y Ediciones, 1972.

Pan-Hispanic Ballad Project, University of Washington, accessible on line: <http:// depts.washington.edu/hisprom $>$ [consulted 7.8.2018].

Petrarch, Francesco, Liber sine nomine (Book without a Name), trans. Norman P. Zacour, Toronto, Pontifical Institute of Medieval Studies, 1973, letter 10.

Plata, Fernando, «On Love and Occasion: A Reading of the "Tale of Innapropriate Curiosity"», in Vibha Maurya and Ignacio Arellano (eds.), Cervantes and Don Quixote: Proceedings of the Delhi Conference on Miguel de Cervantes, Hyderabad, EMESCO, 2008, pp. 195-210.

Teatro Español del Siglo de Oro [TESO], ProQuest, 1997, accessible on line: <http:// teso.chadwyck.com> [consulted 15.7.2018].

Tirso de Molina, El laberinto de Creta, auto sacramental, in Blanca de los Ríos (ed.), Obras dramáticas completas, $2^{\text {nd }}$ ed., Tomo III, Madrid, Aguilar, 1968, pp. 1299-1318.

Schwartz, Lía, «De laberintos: mito y metáfora en textos barrocos. Notas para la historia de su itinerario», Bulletin of Spanish Studies, 90.4-5 (2013), pp. 833-844. 
Wright, Craig, The Maze and the Warrior: Symbols in Architecture, Theology and Music, Cambridge, MA, Harvard University Press, 2001.

Yeats, W.B., «The Second Coming», in The Yeats Reader, ed. Richard J. Finneran, New York, Scribner, 1997, pp. 68-69.

Zayas, María de, La inocencia castigada, in Tres novelas amorosas y tres desengaños amorosos, Madrid, Castalia, 1989, pp. 273-309. 